\title{
A review of K. Kishida's pseudoscorpion taxa (Arachnida, Chelonethi)
}

\author{
Mark L. I. Judson \\ Muséum national d'Histoire naturelle, Département Systématique et Évolution, \\ CNRS UMR 7205, C.P. 53, 57 rue Cuvier, 75005 Paris, France \\ E-mail: judson@mnhn.fr
}

\begin{abstract}
Attention is drawn to the pseudoscorpion taxa published by Kyukichi Kishida (1927, 1929, 1940, 1947), which have been largely ignored in the literature outside Japan. Kishida (1929) was the first author to employ the names Chthonioidea Daday, 1888, Cheliferoidea Risso, 1826, Feaelloidea Ellingsen, 1906, Garypoidea Simon, 1879 and Olpioidea Banks, 1895 at the superfamilial rank, and the first to use the names Olpiidae Banks, 1895 and Pseudogarypidae Chamberlin, 1923 at the familial rank. He was also the first to propose a family-group name based on the genus Atemnus Canestrini, 1884, and is therefore the author of the family Atemnidae Kishida, 1929 and the coordinate subfamily Atemninae Kishida, 1929. The suborders Schizonota Kishida, 1929 and Holonota Kishida, 1929 are polyphyletic. Chelanops nipponicus (Kishida, 1927) is synonymized with Haplochernes boncicus (Karsch, 1881) (new subjective synonymy). Chelifer chamberlini Kishida, 1940, which was apparently described from Harbin, China, is considered a species inquirenda. The pseudoscorpion nomina nuda published by Kishida are listed.
\end{abstract}

Key words - Pseudoscorpions, taxonomy, classification, Japan, China

\section{Introduction}

Kyukichi Kishida (1888-1968) was a pioneer of the study of pseudoscorpions in Japan, publishing several papers on this group between 1915 and 1966. However, little attention has been paid to these papers, even in his own country. Chelonethologists had little motivation to search for them because Morikawa (1960) dismissed all but one of Kishida's pseudoscorpion taxa as invalid, writing that "they have never been described scientifically". The exception was Microcreagris cyclica Kishida, 1928, which Morikawa regarded as synonym of Microcreagris japonicus Ellingsen, 1907. It is therefore not surprising that Kishida's other pseudoscorpion names have been ignored. The catalogues of Harvey $(1991,2009)$ list $M$. cyclica (as a synonym of $B$. japonica) and two nomina nuda: Chelifer nipponicus Kishida, 1927 and Orideobisium takanoanum Kishida, 1966. Contrary to Morikawa's (1960) interpretation, however, several taxa named by Kishida were validly published in terms of the International Code of Zoological Nomenclature (1999), which means that their status needs to be reconsidered.

Kishida wrote prolifically on a wide variety of animal groups (Ono 2005), but there are a number of problems with his publications, particularly those that appeared (or were supposed to appear) in Lansania (subtitled Journal of arachnology and zoology), which he edited from 1921 to 1949 (Ono 2005; Tennent et al. 2008). This journal had a limited distribution and is now extremely rare (Tennent, Yasuda \& Morimoto 2008). Unfortunately, Kishida often cited unpublished manuscripts as though they were published, sometimes even giving the name of the journal and the volume number. An example of this is provided by Kishida's (1966) reference to a paper by him entitled "Biotic systems of Chelonethida", which was supposedly published in Lansania volume 20 (part 3), in 1942. In fact, no such volume of Lansania ever appeared (Tennent et al. 2008) and it is clear that this paper was never published in terms of the requirements of the International Code of Zoological Nomenclature. As explained by Tennent et al. (2008), Kishida considered it quite normal to cite papers that were scheduled for publication, with the year given being that of the completion or submission of the manuscript. In other cases, when the place of publication is given simply as "Tokyo" it is usually safe to assume that the reference concerns a manuscript. As far as I have been able to determine, nine articles on pseudoscorpions were actually published by Kishida $(1915,1927,1928,1929 a, 1929 b$, 1940, 1947, 1948, 1966).

The interpretation of names published in Lansania varies between different authors and taxonomic groups. Tennent et al. (2008: footnote 15) wrote that the "Overall scarcity and highly restricted distribution of Lansania raises a question of whether new names proposed in some parts of the journal can be considered to have been formally published, in the sense of what is recognised as a publication by the International Commission on Zoological Nomenclature." For a work to be validly published, the Code requires that it satisfies the following conditions:

"8.1.1. it must be issued for the purpose of providing a 
public and permanent scientific record,

8.1.2. it must be obtainable, when first issued, free of charge or by purchase, and

8.1.3. it must have been produced in an edition containing simultaneously obtainable copies by a method that assures numerous identical and durable copies."

At least the first two volumes of Lansania appear to meet these conditions (see Tennent et al. 2008 for a discussion of problems with later volumes). The names and nomenclatural acts published by Kishida (1929b) are therefore considered available here. The names of taxa described in Lansania are currently treated as valid for other groups, such as flies (Sabrosky 1999) and spiders (Platnick 2009).

\section{Kishida's 1929 classification of Chelonethi}

Historical accounts of the various classifications proposed for pseudoscorpions have been given by Chamberlin (1931), Harvey (1988) and Murienne et al. (2008), but none of these mentions Kishida's (1929b) classification. Indeed, despite being summarized in the more widely available paper of Takashima (1949), no author outside Japan has referred to Kishida's classification in a taxonomic context. Harvey (1991) listed most of Kishida's papers (along with three unpublished manuscripts), but the only ones he had consulted were Kishida 1928 and 1966. Because Kishida's classification contains a number of nomenclatural acts, it needs to be taken into account.

The classification of pseudoscorpions presented by Kishida (1929b) was based on that of Banks (1895), which he had adopted in an earlier publication (Kishida 1915). Banks' classification, which was originally proposed in the form of a key, is summarized below, with authors and dates of taxa added (generic names in parentheses are those assigned to the higher groups by Banks, who only treated the genera recorded in North America):

Order Pseudoscorpionida

Family Cheliferidae Risso, 1826

Subfamily Garypinae Simon, 1879 (Garypus L. Koch, 1873)

Subfamily Cheliferinae Risso, 1826 (Chelifer Geoffroy, 1762; Chelanops Gervais, 1849)

Family Obisiidae Sundevall, 1833

Subfamily Olpiinae Banks, 1895 (Olpium L. Koch, 1873; Atemnus Canestrini, 1884)

Subfamily Obisiinae Sundevall, 1833

Tribe Ideobisiini Banks, 1895 (Ideobisium Balzan, 1892; Ideoroncus Balzan, 1887)

Tribe Chthoniini Daday, 1888 (Chthonius C. L. Koch, 1843; Lechytia Balzan, 1892)

Tribe Obisiini Sundevall, 1833 (Obisium Leach, 1817; Blothrus Schiödte 1847)

\footnotetext{
${ }^{1}$ The name Schizonota was erroneously repeated instead of Holonota in Kishida's (1929b) table; this error was corrected by Takashima (1949).
}

Kishida's (1929b) classification, published in tabular form, was as follows (authors and dates of taxa added; asterisk indicates first use of coordinate name at given rank):

Order Chelonethida

Suborder Schizonota Kishida, 1929

Superfamily Cheliferoidea Risso, 1826* Family Cheliferidae Risso, 1826

Superfamily Garypoidea Simon, 1879* Family Garypidae Simon, 1879

Family Cheiridiidae Hansen, 1894*

Suborder Holonota Kishida, 1929

Superfamily Atemnoidea Kishida, 1929 Family Atemnidae Kishida, 1929

Superfamily Feaelloidea Ellingsen, 1906* Family Feaellidae Ellingsen, 1906 Family Pseudogarypidae Chamberlin, 1923*

Superfamily Chthonioidea Daday, 1888* Family Tridenchthoniidae Balzan, 1892 Family Chthoniidae Daday, 1888

Superfamily Ideobisioidea Banks, 1895* Family Ideobisiidae Banks, 1895

Superfamily Olpioidea Banks, 1895* Family Olpiidae Banks, 1895*

Superfamily Obisioidea Sundevall, 1833* Family Obisiidae Sundevall, 1833

The novelty of this scheme lies in the elevation of the ranks of most of the groups recognized in Banks' classification. Thus families, subfamilies and tribes became suborders, superfamilies and families, respectively. The composition of Feaelloidea followed Chamberlin (1923a), while that of Chthonioidea followed Hansen (1894). Chamberlin's (1923b) introduction of Sternophorinae as a subfamily of Cheliferidae seems to have been overlooked.

Kishida's classification, like that of Banks, is clearly artificial, dividing pseudoscorpions into two groups according to the presence or absence of carapacic furrows. Kishida (1929b) interpreted the presence of furrows as a primitive feature, reflecting the original separation of distinct sclerites, and proposed the suborder Schizonota Kishida, 1929 , for this group. Those families without furrows were assigned to the new suborder Holonota Kishida, 1929'. The presence of furrows is now generally acknowledged to be a derived feature in pseudoscorpions (e.g. Chamberlin 1931). Except for the position of the family Atemnidae, the suborders Schizonota and Holonota correspond to Balzan's (1892) Panctenodactyli and Hemictenodactyli, respectively. The homonymous name Holonota Balogh, 1972 has been proposed for an unranked group of oribatid mites (Balogh 1972; Haumann 1991).

\section{Taxa validly published by Kishida}

Cheliferoidea Risso, 1826

Cheliferides Risso 1826: 157.

Atemnoidea Kishida 1929b: 124. 
Cheliferoidea Chamberlin 1931: 239-240.

No other author has followed Kishida's (1929b) concept of a superfamily Atemnoidea. The family Atemnidae clearly belongs in the Cheliferoidea, hence Atemnoidea Kishida, 1929 is a junior subjective synonym of Cheliferoidea Risso, 1826. This synonymy was implicitly made by Chamberlin (1931), when he treated Atemnidae as a family of the Cheliferoidea.

Atemnidae Kishida, 1929

Atemnidae Kishida 1929b: 124; Chamberlin 1931: 243-244.

Authorship of the name Atemnidae has been universally attributed to Chamberlin (1931). However, Kishida's (1929b) Atemnidae and Atemnoidea are the earliest familygroup names based on the generic name Atemnus Canestrini, 1884 and thus have priority over Atemnidae Chamberlin, 1931. Authorship of the co-ordinate names Atemnidae and Atemninae must therefore be attributed to Kishida, 1929.

Bisetocreagris japonica (Ellingsen, 1907)

Microcreagris gigas var. japonica Ellingsen 1907: 7.

Microcreagris gigas japonica (Ellingsen, 1907): Kishida 1915: 367.

Microcreagris japonica (Ellingsen, 1907): Kishida 1928: 408.

Microcreagris cyclica Kishida 1928: 409-411, figs. 1-2.

Microcreagris ishiharanus Morikawa 1952b: 255-256, figs 10-

12 (synonymized with Microcreagris cyclica by Morikawa 1955: 216-217).

Bisetocreagris japonica (Ellingsen, 1907): Ćurčić, Dimitrijević, Makarov \& Lučić 1994: 158-159, tab. 1, figs 22-37.

See Harvey $(1991,2009)$ for other citations of Bisetocreagris japonica.

Kishida's (1928) description and figures of M. cyclica are better than those published in most of his other papers. Morikawa (1955) synonymized Microcreagris ishiharanus Morikawa, 1952 with M. cyclica and later (Morikawa 1960) considered both names to be synonyms of $M$. japonica Ellingsen, 1907. Morikawa's $(1955,1960)$ suggestion that the holotype of M. cyclica was immature is not borne out by Kishida's figure (1928: fig. 1), which shows a trichobothrium in the position expected for $i s b$, which only appears in the adult. The difference in body length can instead be explained by the strong contraction of the body, which is evident in Kishida's drawing. It is also worth noting that Kishida was the first author to raise Ellingsen's (1907) 'variety' japonica to subspecific (Kishida 1915) and later specific (Kishida 1928) rank.

\section{Haplochernes boncicus (Karsch, 1881)}

Chelifer nipponicus Kishida 1915: 367. Nomen nudum.

Chelifer nipponicus Kishida 1927: 955 figs 1-2 (left). New synonymy.
Chelanops nipponicus (Kishida, 1927); Kishida 1947: 1001, fig. 2845; Kishida 1948: 176, fig. 550; Takashima 1949: 21, 22. See Harvey $(1991,2009)$ for other citations of H. boncicus.

The general appearance of Chelifer nipponicus Kishida 1927 and the fact that it was found under bark suggest that it probably belongs in the Chernetidae. Kishida's (1947) transfer of the species to the chernetid genus Chelanops Gervais, 1849 is consistent with this position, even if it included a rather heterogeneous assemblage of cheliferoids in the past. As now understood (Muchmore 1999), Chelanops is restricted to the New World. The form of the palps and the apparent absence of carapacic furrows suggest Haplochernes Beier amongst the genera known from Japan. The only obstacles to placing nipponicus in this genus are the form of the tergites, which are illustrated by Kishida (1927, 1947, 1948) as being undivided (as opposed to divided in Haplochernes), and the form of the spinneret, shown as simple or weakly bifid (as opposed to having several short rami in Haplochernes). I assume that these discrepancies are due to observational errors, because none of the known Japanese pseudoscorpions corresponds to Kishida's descriptions in all respects. Only one species of Haplochernes, H. boncicus (Karsch, 1881), is known from mainland Japan (another species, H. boninensis Beier, 1957, is restricted to the Ogasawara Is.). Rather than leaving $C$. nipponicus in taxonomic limbo as a nomen dubium, its seems preferable to synonymize it with Haplochernes boncicus (Karsch, 1881).

Chelifer chamberlini Kishida, 1940 species inquirenda Chelifer chamberlini Kishida 1940: 112-115, unnumbered figs on pp. 113 \& 114; Takashima 1949: 22.

Chelifer chamberlini Kishida, 1940 has been overlooked by all authors except Takashima (1949). This species was described by Kishida (1940) in a popular science magazine (Kagaku-gahou). Kishida (1940) attributed authorship of the name to "Kishida 1939", but this is probably another example of his dating species to the time of submission of a manuscript. The type locality appears to be Harbin, Heilongjiang Province, Northeast China, where the collector (Yasuhisa Shinotsuka) was living and studying at the Junior High School (Shinotsuka 1940; Kishida 1940). Kishida's figures (reproduced here as Figs 1-2) show two somewhat different cheliferids. The first (Fig. 1) has a more elongate body and palps, and the paraxial margin of the chela is more rounded. These differences might reflect sexual dimorphism, different developmental stages, or a confusion of two species. Because Harbin has a cold winter climate, it is unlikely that $C$. chamberlini belongs to any of the tropical or subtropical Asian genera of Cheliferidae. One possibility is that it belongs to the genus Macrochelifer Vachon, which is present in Tibet (Vachon 1940) and the Tien Shan region of China (unpubl. obs.). Because the type material is presumably lost, a certain attribution will only be possible when 

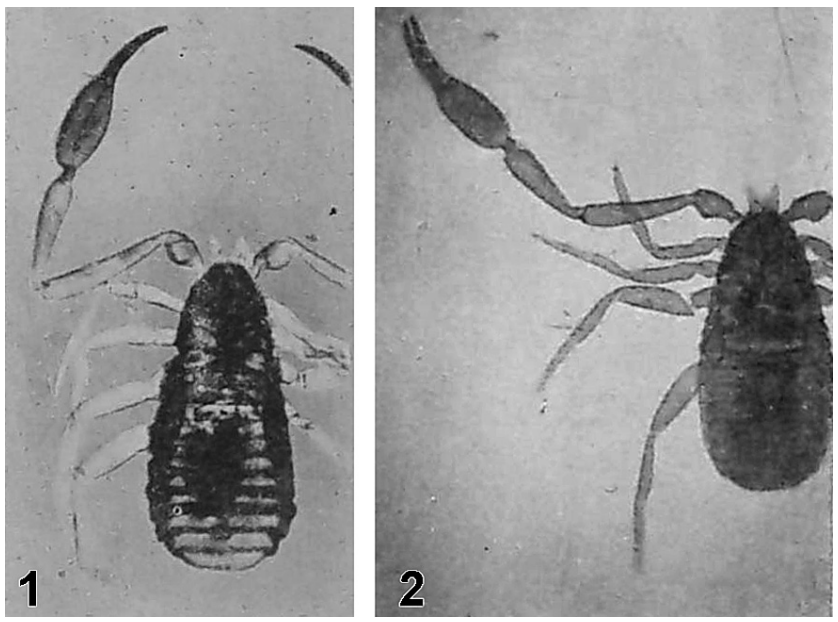

Figs. 1-2. Chelifer chamberlini Kishida, 1940 (species inquirenda). - 1, photograph reproduced from Kishida (1940: 113); 2, photograph reproduced from Kishida (1940: 114).

topotypic material becomes available.

\section{Nomina nuda published by Kishida}

Kishida (1915: 367) introduced six species names without providing descriptions:

Chelifer ellingseni Kishida, 1915, nomen nudum [junior homonym of Chelifer ellingsenii With, 1908];

Chelifer nipponicus Kishida, 1915, nomen nudum;

Chelifer odateanus Kishida, 1915, nomen nudum;

Chelifer sasakii Kishida, 1915, nomen nudum;

Chthonius yatsui Kishida, 1915, nomen nudum;

Ideobisium nipponicum Kishida, 1915, nomen nudum.

All of these names were cited by Takashima (1949) and Morikawa (1960), but they were not included in the list of nomina nuda given by Harvey (1991, 2009). Only C. nipponicus appears to have been made available later, as Chelifer nipponicus Kishida, 1927.

Kishida (1947) used the combination Gnathochthonius japonicus (Ellingsen, 1907) without explanation. Because no diagnosis of the genus was provided, Gnathochthonius Kishida, 1947 is a nomen nudum. Kishida's $(1927,1947)$ identification of the species as japonicus was also probably incorrect. The posteriorly constricted carapace and the numerous carapacic setae shown in his figures (1927: unnumbered fig.; 1947: fig. 2847) suggest a species of the genus Allochthonius Chamberlin, 1929, which is common in Japan. Chthonius japonicus Ellingsen, 1907 has only recently been confirmed as belonging to the genus Tyrannochthonius Chamberlin, 1929 (as first suggested by Beier 1932) by Sakayori (2002), who showed that Tyrannochthonius japonicus (Ellingsen) sensu Morikawa (1960) was misidentified.
Finally, Kishida (1966: 7) referred to an undescribed genus and species of Ideobisiidae, based on an unpublished manuscript by him, entitled "Biotic systems of Cheloneth$i d a "$ and dated 1942:

Orideobisium Kishida, 1966 nomen nudum.

Orideobisium takanoanum Kishida, 1966 nomen nudum.

Because no description of takanoanum has been published and no valid species has been associated with Orideobisium, both names are invalid.

\section{ACKNOWLEDGEMENTS}

I am much indebted to Dr Hirotsugu Ono (National Museum of Nature and Science, Tokyo) for providing copies of Kishida's publications and help with interpreting their contents. Dr Hirokazu Ozawa (National Museum of Nature and Science, Tokyo) and Dr Akio Tanikawa (University of Tokyo) provided copies of additional publications by Kishida. Parts of Japanese texts were kindly translated by Emiko Iinuma (Institute d'Orient, Paris). Information concerning the journal Lansania was provided by Dr Joachim Haupt (Berlin), Mr John Tennent (The Natural History Museum, London) and Dr Masatoshi Yasuda (Forestry and Forest Products Research Institute, Kumamoto). Helpful comments on the text were made by Dr Volker Mahnert (Muséum d'Histoire naturelle, Geneva) and two anonymous referees.

\section{References}

Balogh, J. 1972. Oribatid Genera of the World. Akadémiai Kiadó, Budapest, 188 pp., 71 pls.

Balzan, L. 1892. Voyage de M. E. Simon au Venezuela (Décembre 1887-Avril 1888). Arachnides. Chernetes (Pseudoscorpiones). Ann. Soc. entomol. France, 60: 497-552.

Banks, N. 1895. Notes on the Pseudoscorpionida. J. New York entomol. Soc., 3: 1-13.

Beier, M. 1932. Pseudoscorpionidea I. Subord. Chthoniinea et Neobisiinea. Tierreich, 57: $\mathrm{i}^{-} \mathrm{xx}, 1^{-258}$.

Chamberlin, J. C. 1923a. The genus Pseudogarypus Ellingsen (Pseudoscorpionida - Feaellidae). Entomol. News, 34: 146-149, 161-166, pl. 5 .

Chamberlin, J. C. 1923b. New and little known pseudoscorpions, principally from the islands and adjacent shores of the Gulf of California. Proc. Calif. Acad. Sci., Ser. 4, 12: 353-387.

Chamberlin J. C. 1931. The arachnid order Chelonethida. Stanford Univ. Publ., Ser. Biol. Sci., 7: 1-284.

Ćurčić, B. P. M., Dimitrijević, R. N., Makarov, S. E. \& Lučić, L. R. 1994. Further revision of some North American and Japanese false scorpions originally assigned to Microcreagris Balzan, 1892 (Neobisiidae, Pseudoscorpiones). Zb. rad. Odb. kras speleologiju, Srp. Akad. Nauka Umet. (Recl. Rapp. Com. karst spéléol., Acad. serbe Sci. Arts), 5: 145-164.

Ellingsen, E. 1907. On some pseudoscorpions from Japan collected by Hans Sauter. Nyt Mag. Naturvidensk., 45: 1-17.

Hansen, H. J. 1893-1894. Organs and characters in different orders of arachnids. Entomol. Meddel., 4 (2/3): 137-144, pl. 2-3 [1893], 4 (4/5): 145-249, pl. 4-5 [1894].

Harvey, M. S. 1988. The systematics and biology of pseudoscorpions. Pp. 75-85. In: Austin, A. D. \& Heather, N. W. (eds) Australian Arachnology. Miscellaneous publication 5, Australian Entomological Society, Brisbane, $137 \mathrm{pp}$.

Harvey, M. S. 1991. Catalogue of the Pseudoscorpionida. Manchester: Manchester Univ. Press, 726 pp.

Harvey, M. S. 2009. Pseudoscorpions of the World, version 1.2. Western Australian Museum, Perth (online catalogue available at 
http://www.museum.wa.gov.au/arachnids/pseudoscorpions).

Haumann, G. 1991. Zur Phylogenie primitiver Oribatiden (Acari: Oribatida). Dbv-Verlag für die Technische Universität Graz, Graz, $237 \mathrm{pp}$.

International Commission on Zoological Nomenclature. 1999. International Code of Zoological Nomenclature, 4th edn. International Trust for Zoological Nomenclature, London, $306 \mathrm{pp}$.

Kishida, K. 1915. [A study on the pseudoscorpions of Japan.] Saiensu [Science], Kyoto, 5 (9): 362-369 (in Japanese).

Kishida, K. 1927. Chthonius japonicus Ellingsen, Obisium pygmaeum Ellingsen, Chelifer nipponicus Kishida. Pp. 954-955. In: Hirase, S., Hozawa, S., Izuka, A. et al., Nihon Dobutsu Zukan [Figuraro de Japanaj Bestoj=Illustrated Encyclopaedia of the Fauna of Japan]. Hokuryukwan \& Co., Tokyo, $10+2168+68+$ 172 pp., 21 pls (in Japanese).

Kishida, K. 1928. Pseudoscorpions (Microcreagris) of Japan. Annot. Zool. Jap. 11: 407-413.

Kishida, K. 1929a. [On the localities of a Japanese chelifer, Roncus japaonicus [sic].] Lansania 1 (3): 39 (in Japanese).

Kishida, K. 1929b. [On the criteria to classify chelifers.] Lansania, 1 (8): 124 (in Japanese).

Kishida, K. 1940. Shinotsukakanimushi ni tsuite. [Study of Shinotsuka's pseudoscorpion]. Kagaku-gahou (La Scienca Grafikajo [Science Pictorial]), 29 (6): 112-115 [lower two-thirds of pages] (in Japanese).

Kishida, K. 1947. Hina kani mushi, Chelanops japonicus Kishida; Chibi kaku kani mushi (Chibi yotsumé kani mushi), Microbisium pygmaeum Ellingsen; Agitotsu kani mushi (yotsumé kani mushi, Tsuchi kani mushi), Gnathochthonius japonicus Ellingsen. P. 1001. In: Uchida, S. et al. (eds) Illustrated Encyclopaedia of the Fauna of Japan (revised edition). Hokuryukwan \& Co., Tokyo, 10+1898+ $18+20+108+89$ pp., 12 pls (in Japanese).

Kishida, K. 1948. Chelanops nipponicus Kishida. P. 176. In: Nihon Dobutsu Zukan (Illustrated Encyclopaedia of the Fauna of Japan, Edition for students). Hokuryukwan \& Co., Tokyo, $7+422+6+10$ pp. (in Japanese).

Kishida, K. 1966. On the altitudinal distribution of the Chelonethida in Japan. Acta arachnol., 20: 6-8.

Morikawa, K. 1955. Pseudoscorpions of forest soil in Shikoku. Mem. Ehime Univ., Sect. II, Ser. B, 2: 215-222.

Morikawa, K. 1960. Systematic studies of Japanese pseudoscorpions. Mem. Ehime Univ., Sect. II, Ser. B, 4: 85-172.

Muchmore, W. B. 1999. Redefinition of the genus Chelanops Gervais (Pseudoscorpionida: Chernetidae). Pan-Pac. Entomol., 75:
$103-111$.

Murienne, J., Harvey, M. S. \& Giribet, G. 2008. First molecular phylogeny of the major clades of Pseudoscorpiones (Arthropoda: Chelicerata). Mol. Phylo. Evol., 49: 170-184.

Ono, H. 2005. Revision of spider taxa described by Kyukichi Kishida: Part 1. Personal history and a list of his works on spiders. J. Arachnol., 33: 501-508.

Platnick, N. I. 2009. The world spider catalog, version 10.0. American Museum of Natural History, New York (online catalogue available at http://research.amnh.org/entomology/spiders/catalog/ index.html).

Risso, A. 1826. Histoire naturelle des principales productions de 1'Europe méridionale et particulièrement de celle des environs de Nice et des Alps maritimes. Vol. 5. F.G. Lerault, Paris, viii +383 pp.

Sabrosky, C. W. 1999. Family-group names in Diptera: an annotated catalog. Myia, 10: 1-360.

Sakayori, H. 2002. Postembryonic development of a Japanese soildwelling pseudoscorpion, Tyrannochthonius japonicus (Pseudoscorpionida: Chthoniidae). Bull. Ibaraki Nature Mus., 5: 57-67.

Shinotsuka, Y. 1940. Boku no sukina saishu to kanimushi no hakken. [Collecting is my pleasure, and the discovery of a pseudoscorpion] Kagaku-gahou (La Scienca Grafikajo [Science Pictorial]), 29 (6): 112-115 [upper third of pages] (in Japanese).

Takashima, H. 1949. [Studies on Japanese pseudoscorpions 1]. Acta arachnol., 10: 9-31 (in Japanese).

Tennent, W. J., Yasuda, M. \& Morimoto, K. 2008. Lansania Journal of arachnology and zoology - a rare and obscure Japanese natural history journal. Arch. nat. Hist., 35: 252-280.

Vachon, M. 1940. Remarques sur Macrochelifer, nouveau genre de Pseudoscorpions. Bull. Mus. natn. Hist. nat., Paris, Ser. 2, 12 412-414.

Unpublished manuscripts cited in the literature (none seen, presumably all in Japanese)

Kishida, K. 1920. On a pseudoscorpion, Microcreagris formosana from Formosa, 6 pp. [cited by Kishida 1928].

Kishida, K. 1930. 26 families of the order Chelonethida. Tokyo, 16 pp. [cited by Kishida 1966].

Kishida, K. 1942. Biotic systems of Chelonethida. Lansania, 20 (3) [issue never published], 5 pp. [cited by Kishida 1966].

Kishida, K. 1945. Idiobiologia chelonethidarum. Tokyo (in Japanese) [cited by Kishida 1966].

Received December 21, 2009 / Accepted February 10, 2010 